\title{
Pengembangan Sistem Prepaid Internet Card Sebagai Metode Bill Payment Transaction \\ Berbasis Qrcode Di Suryamegah.Net Kota Malang
}

\author{
Muhammad Zainul ${ }^{1}$, Citra Kurniawan ${ }^{2}$ \\ Sekolah Tinggi Teknik Malang ${ }^{12}$ \\ zha.nathapong@gmail.com ${ }^{1}$ \\ airakurniawan@gmail.com ${ }^{2}$
}

\begin{abstract}
The security is aspect important for any infromationsystem.System need security who fuction to protect the data owner of an information. in the process or actifity of protection the data the System needs a login system security. The information security method of each user is very important to be secret, the method used in this research is QRCode based method. QRCode is a two dimensional image matrix that can save data. Payment system is a software have function to record the nominal payment and time internet activities and other facilities. Payment system is a tool used in Suryamegah.Net.
\end{abstract}

Keyword : Login Security, Barcode, Payment system

\section{ABSTRAK}

Keamanan merupakan aspek penting dari suatu sistem informasi. sebuah sistem membutuhkan keamanan yang berfungsi menjaga data-data pemilik suatu informasi, dalam aktifitas menjaga data-data adalah keamanan sistem login. metode keamanan informasi dari setiap pengguna sangat penting untuk dirahasiakan, metode yang digunakan adalah QRCode. QRCode merupaka image matrix dua dimensi yang dapat menyimpan data. Sistem pembayaran merupakan suatu software yang berfungsi untuk merekam nominal pembayaran dan waktu aktifitas internet dengan berbagai fasilitas lainnya. Sistem pembayaran merupakan alat yang dipergunakan di Suryamegah.Net.

Kata kunci : Keamanan, Barcode, Sistem pembayaran

\section{PENDAHULUAN}

Pada era informasi saat ini berbagai jenis sarana informasi yang berkembang dengan pesat. Perkembangan teknologi informasi modern dapat membantu user (pengguna) dalam melakukan berbagai aktifitas. Perkembangan teknologi menuntut perusahaan untuk melakukan perubahan sesuai dengan kebutuhan demi terciptanya keamanan dan kenyamanan fasilitas yang disediakan untuk para pengguna. Sistem manual tidak sesuai jika diterapkan dalam sistem pembayaran, sistem manual mempunyai banyak kekurangan. Sistem pembayaran membutuhkan mekanisme yang dapat melindungi data dari pengguna yang tidak berhak. Masalah keamanan merupakan masalah yang penting dan utama dalam sistem komputer yang terhubung dalam suatu 
jaringan. Data maupun informasi menjadi target serangan oleh pihak-pihak yang tidak bertanggung jawab sehingga perlu untuk menjaga integritas data dan informasi.

Keamanan yang dipergunakan yaitu dengan menerapkan QRCode sebagai media penyimpanana informasi dari setiap user. QRCode adalah QRCode (Quick Response Code) adalah image berupa matriks dua dimensi yang memiliki kemampuan untuk menyimpan data didalamnya. QRCode merupakan perkembangan dari kode batang (barcode).

Sistem manual yang masih berlaku di warnet pada transaksi login username, user banyak melakukan keselahan saat mengisi username secara manual. Untuk mengatasi kesalahan saat mengisi username maka pihak warnet diharuskan memperhatikan keamaan sistem login billing yang di terapkan di warnet. Dengan sistem billing yang ada di warnet masih menggunakan sistem login manual, diharapkan warnet dapat mengaplikasikan mesin barcode scanner supaya warnet dapat menjamin keamaan dalam login user, efektif dalam melakukan transaksi login billing, dan menjaga nominal prabayar yang dilakukan oleh user.

\section{TINJAUAN PUSTAKA}

\subsection{Payment system}

Setiap aktifitas yang dilakukan manusia dalam melakukan transaksi, baik transaksi sederhana maupun transaksi modern yang berkaitannya dengan uang maka dilihat dari garis bersarnya adalah melakukan transaksi pembayaran. Sistem pembayaran (Payment System) adalah sistem yang berhubungan dengan transfer dari jumlah nilai uang dari satu pihak ke pihak lain. Sistem pembayaran (Payment System)mempunyai dua layanan yang dapat memudahkan pengguna untuk melakukan transaksi pembayaran yaitu sistem pembayaran prabayar dan pascabayar. Untuk pengelolaan tagihan pembayaran serta deposit yang efektif, maka layanan sistem pembayaran tagihan prabayar yang sesuai. Pembayaran prabayar yaitu pembayaran atau pengisian deposit yang dilakukan oleh user sebelum dipergunakan untuk melakukan transaksi, sedangkan pembayaran pascabayar yaitu pembayaran yang dilakukan diakhir setelah penggunaan, tagihan akan di bayar setelah jangka waktu yang ditentukan.

\subsection{Sistem Login}

Keamanan dan kerahasiaan data merupakan salah satu aspek penting dari suatu sistem informasi. Sebuah sistem membutuhkan keamanan yang berfungsi menjaga data-data pemilik suatu informasi. Data password yang dimiliki user harus dapat dilindungi atau dijaga dari orang-orang yang tidak berhak untuk mengakses informasi yang bukan haknya tersebut. Sebuah sistem mutlak membutuhkan keamanan data, dalam proses/aktifitas menjaga data-data tersebut maka sistem perlu sebuah keamanan sistem login.

Pengertian sistem login sistem login merupakan proses untuk mengakses komputer dengan memasukkan identitas dari akun pengguna dan kata sandi untuk mendapatkan hak akses menggunakan sumber daya komputer tujuan. Proses sistem login mempunyai beberapa tahap untuk melakukan aktifitas keamanan yaitu identifikasi, authentikasi, dan otorisasi.

\subsection{Barcode}

Metode sistem pembayaran modern serta menghemat waktu dalam melakukan transaksi dan menjaga keamanan data-data, 
maka sistem pembayaran yang dilengkapi dengan barcode dapat mengatasi masalah tersebut. Barcode adalah merupakan sebuah kode yang berbentuk menyerupai batang. Barcode terdiri dari sebuah bentuk bar dan space (batang hitam dan spasi putih) dalam rasio tertentu yang didefinisikan yang mempresentasikan karakter alphanumerik. Barcode dibaca kode-kodenya dengan menggunakan barcode reader.

\subsection{Barcode Reader}

Penggunaan barcode reader pada sistem pembayaran modern saat ini dapat membantu manusia dalam melakukan transaksi pembayaran dengan sangat cepat dan transaksi yang aman. Pengertian barcode reader adalah perangkat untuk membaca kode-kode yang berada pada barcode, hanya dengan mendekatkan barcode reader secara auto maka sinar lasir akan membaca, barcode reader membaca bar putih hitam pada barcode yang tercetak dengan sangat akurat dan cepat. Pada perkembangan sinar laser yang berada pada barcode reader dipancarkan tidak hanya sebentuk horizontal saja akan tapi berupa kombinasi pola yang sangat rumit sehingga mampu membaca barcode dari sisi sudut manapun saat melakukan scanning.

\subsection{Bill Payment Transaction}

Pada awal ditemukannya komputer, manusia menggunakan komputer untuk mempermudah proses perhitungan. Sampai sekarang komputer sudah banyak sekali mengalami perkembangan. Penggunaan komputer pada saat ini tidak hanya terbatas untuk proses perhitungan. Pengolahan data, multimedia, internet merupakan sebagian dari fungsi komputer yang banyak dipakai manusia. Seiring dengan perkembangan komputer di Indonesia, maka perkembangan bisnis di bidang ini pun cukup banyak mengalami kemajuan. Warung internet (warnet) merupakan bisnis yang sedang mengalami kemajuan pada saat sekarang ini. Penghitungan biaya yang akurat dan cepat sangat diperlukan dalam bisnis warnet. Untuk itu para pelaku bisnis di bidang ini sangat memerlukan perangkat lunak untuk membantu proses perhitungan waktu dan biaya. Aplikasi yang membantu proses perhitungan waktu dan biaya biasa disebut sistem penghitungan pembayaran (billing). Billing yang baik adalah yang dapat menghitung secara akurat dan cepat.

\section{METODE}

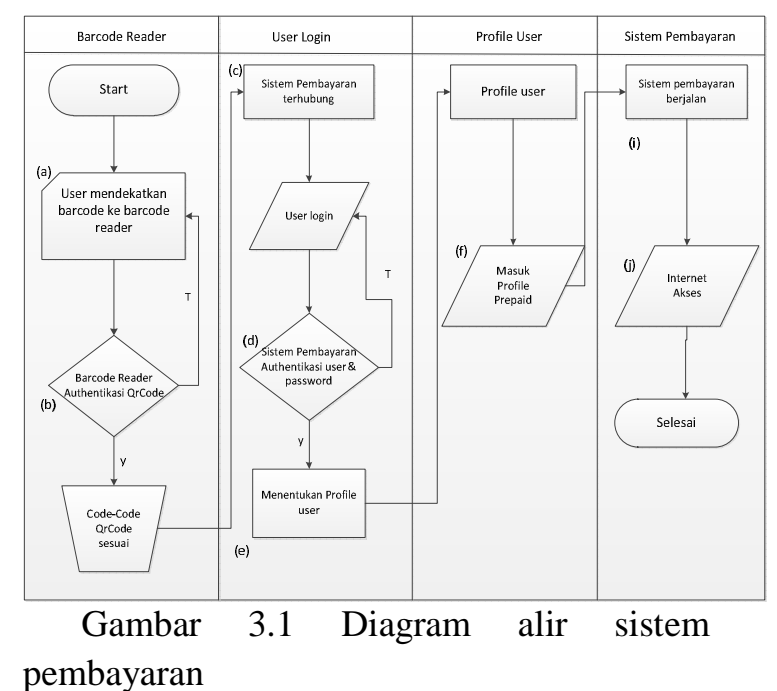

Alur dari penggunaan sistem pembayaran modern ini sebagai berikut :

1. Profile user prepaid mendekatkan prepaid internet card terhadap barcode reader. Dengan melakukan hal tersebut, maka sistem dari barcode reader secara automatic membaca QR Code yang terdapat pada prepaid internet card (a). Jika barcode reader dapat menterjemahkan $\mathrm{QR}$ Code, maka 
sistem pembayaran akan terhubung, berlaku sebaliknya jika barcode reader tidak dapat menterjemahkan QR Code maka user akan diminta untuk mendekatkan lagi ke barcode reader untuk membaca code-code dari QR Code kembali (b).

2. Profile user prepaid jika sudah berhasil terhubung dengan sistem pembayaran maka (c), sistem pembayaran akan melakukan aktifitas authentikasi data-data yang dimiliki oleh profile user prepaid terhadapa database, jika data-data benar maka sistem pembayaran akan menentukan profile user tersebut, berlaku demikian jika authentikasi data-data user salah maka sistem pembayaran meminta mengulangi lagi (d).

3. User yang telah berhasil login akan ditentukan profilenya oleh sistem pembayaran (e), sistem pembayaran mempunyai beberapa profile user seperti reguler, paket, game dan prepaid. Jika user tersebut adalah user prepaid maka akan masuk kedalam profile prepaid. Sistem prepaid mempunyai kelebihan dari pada profile user lainnya yaitu potongan harga pada setiap transaksi dengan ketentuan yang sudah disetting oleh admin (f).

4. Aktifitas login yang dilakukan oleh user sudah berhasil (i), alur selanjutnya adalah sistem pembayaran yang akan berjalan untuk selalu menampilkan waktu yang terdapat pada perangkat komputer dan untuk aktifitas akses internet sudah bisa dilakukan (j).

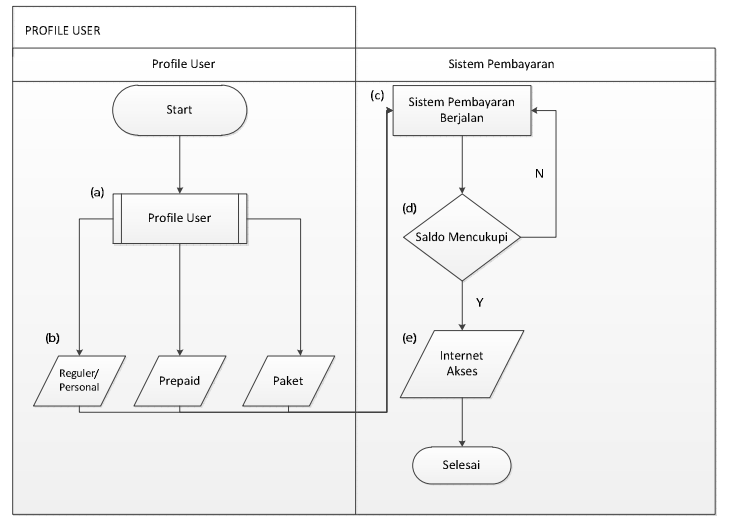

Gambar 3.2 Diagram alir Profile user dalam sistem pembayaran

Profile user memiliki fungsi sebagai pembagian dalam melakukan aktifitas login, profile user mempunyai beberapa pilihan untuk melakukan login terhadap sistem pembayaran tagihan. Dalam penelitian saat ini, profile user dibedakan beberapa pilihan untuk login yaitu Reguler, Prepaid dan paket. Berikut adalah penjelasan dari diagram alir profile user dalam sistem pembayaran tagihan.

1. User terhubung ke profile user yang terdapat pada sistem pembayaran tagihan (a).

2. Dalam sistem pembayaran terdapat profile user untuk menentukan kemana user tersebut akan login, dalam profile user sistem pembayaran ada tiga macam user yang penulis tampilkan, yaitu Reguler/Personal, Prepaid dan Paket (b).

3. Masing-masing user akan menentukan profile user yang sudah tersedia. Dalam penulisan ini maka, profile prepaid yang akan dipilih sebagai profile user. User akan terhubung terhadap sistem pembayaran (c). Dalam proses ini jika saldo yang terdapat dalam prepaid tidak mencukupi maka proses harus kembali ke sistem pembayaran dan user tidak dapat melakukan aktifitas akses internet (e). Sebaliknya jika saldo yang terdapat pada 
prepaid mencukupi maka aktifitas selanjutkan adalah sistem pembayaran akan terbuka dan user dapat melakukan aktifitas akses internet.

\section{HASIL DAN PEMBAHASAN}

Pembayaran tagihan menggunakan metode QRCode merupakan suatu sistem modern yang mengutamakan keamanan dari setiap data atau informasi user, sehingga user lain tidak dapat menggunakan prepaid internet card yang bukan hal miliknya. Prepaid internet card adalah kartu yang dilengkapi dengan QRCode yang berfungsi sebagai penyimpanan data atau informasi untuk melakukan transaksi login, topup, dan

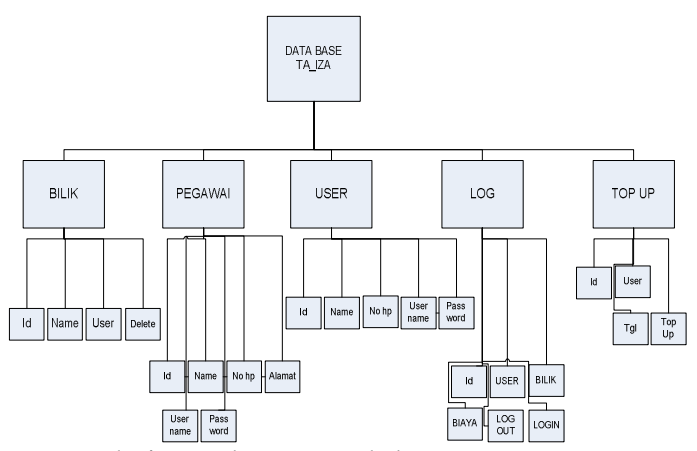

transaksi pembayaran dalam warnet.

Gambar 4.1 Struktur database sistem pembayaran.

Struktur database menampilkan aliran data dari field-field yang saling berhubungan, dengan adanya struktur database diharapkan dapat mempermudah dalam pengembangan sistem pembayaran yang menggunakan metode QRCode.

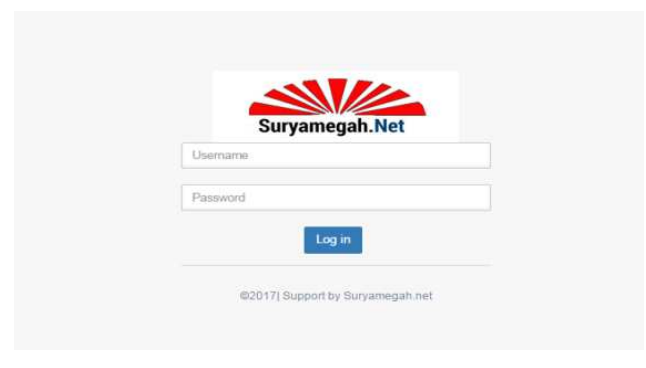

4.2 tampilan login

Halaman login sistem merupakan halaman awal admin yang tujuannya untuk mengakses sistem pembayaran. Halaman login sistem pembayaran dilengkapi dengan keamanan sistem login yaitu username dan password. Sistem pembayaran akan berjalan jika admin login terhadap halaman login dengan menggunakan username dan password yang sesuai

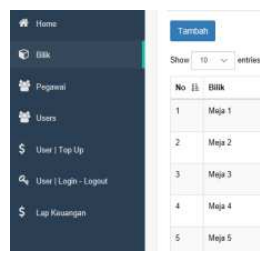

\section{3 tampilan home}

Halaman Home pada sistem pembayaran menampilkan beberapa biodata dari Suryamegah.Net. biodata tersebut meliputi Nama warnet, Alamat warnet. No telp warnet dan sosial media warnet. 


\section{4 tampilan bilik}

Halaman bilik pada sistem pembayaran
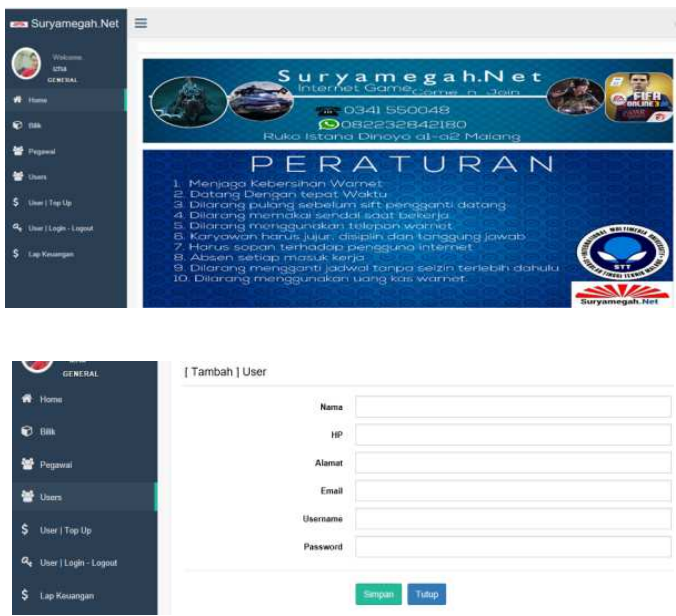

menampilkan urutan dari meja atau nomer komputer yang siap dipergunakan oleh user. Pada sistem pembayaran seorang karyawan berhak memilihkan nomer komputer yang siap dipergunakan.
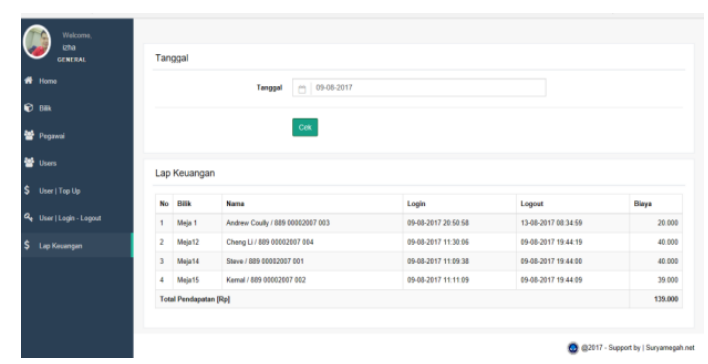

4.5 tampilan halaman Add User

Halaman tambah user berfungsi sebagai media untuk membuat biodata dari user yang selanjutnya akan disimpan. Halaman tambah user meliputi Nama, Nomor Hp, Alamat, Username dan password
Halaman Login dalam halaman login dan logout berfungsi untuk memasukan codecode barcode yang terdapat pada prepaid

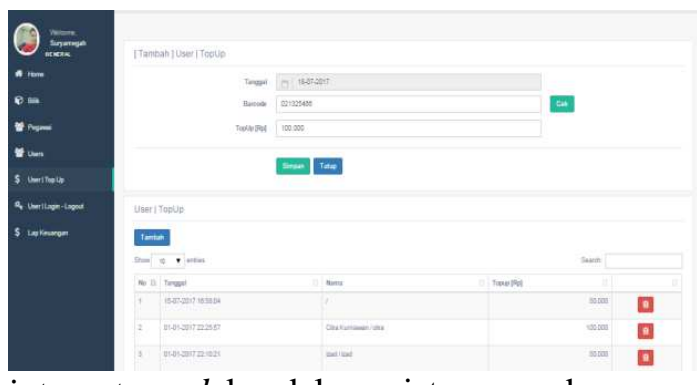

internet card ke dalam sistem pembayaran. Seorang karyawan hanya perlu meletakkan kursor terhadap kolom barcode selanjutnya pilih cek dan memilihkan nomor komputer yang siap untuk dipergunakan oleh user. Sistem pembayaran akan melakukan authentikasi, jika authentikasi username dan password benar maka sistem pembayaran akan mengizinkan user untuk melakukan akses internet dan jika authentikasi gagal maka user tidak dapat melakukan akses internet.

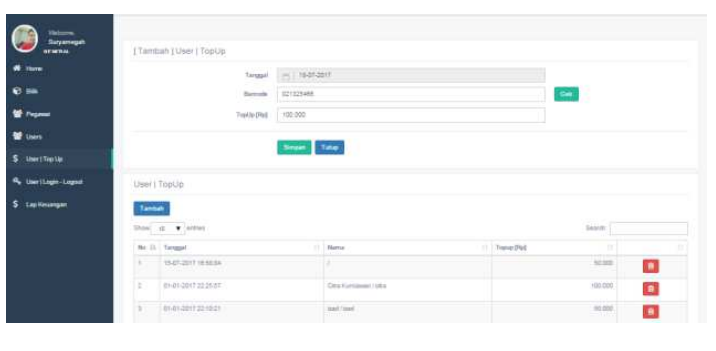

\subsection{Halaman topup}

Halaman TopUp user adalah halaman yang menyediakan layanan penambahan nominal. Penambahan nominal yang bertujuan untuk menambah waktu dalam transaksi internet hal ini dilakukan oleh seorang karyawan. Karyawan hanya men scan barcode yang berada pada prepaid 
internet card selanjutnya dipilih tombol cek dalam menu topup dan disini nominal yang ditambahkan.

\section{KESIMPULAN DAN SARAN}

Berdasarkan dari pembahasan pada bab sebelumnya, maka peneliti mengambil beberapa kesimpulan yang telah diperoleh sebagai hasil penelitian, sebagai berikut:

1. Prepaid internet card sebagai metode bill payment transaction sistem sangat mutlak diperlukan, karena sistem ini mudah dalam melakukan transaksi pembayaran tagihan dengan sistem modern.

2. Sistem Prepaid internet card sebagai metode bill payment transaction berbasis $Q R$ Code sangat mengutamakan keamanan dari setiap user yang menggunkan prepaid internet card tersebut karena dilengkapi dengan QRCode yang berfungsi sebagai keamanan dari username dan password pengguna card tersebut.

3. Saran yang dapat disampaikan kepada peneliti lain yang akan melaksanakan penelitian searah dengan penelitian ini, agar lebih meningkatkan sistem keamanan login terhadap semua profile user. Dalam penelitian ini hanya membahas tentang ruang lingkup profile user prepaid.

4. Diharapkan peneliti lain dapat menambah fitu-fitur yang dapat mempermudah user dalam penggunaan prepaid internet card sebagai metode bill payment transaction seperti halnya fitur pemesanan softdrink, penambahan deposit dan melakukan pengaduan eror terhadap komputer maupun internet.

\section{DAFTAR PUSTAKA}

Andreas, Felix., \& Alfa, Jefri. 2010. Model Fragmentasi Sistem Basis Data Terdistribusi Studi Kasus Sistem Member Warnet. Fakultas teknologi Informasi, Universitas Stikubank. 15/TH.II, Juli, hal 83-89.

Diartono, Dwi agus. 2007. Perancangan Aplikasi Sistem Billing untuk Warnet Prabayar, Fakultas teknologi Informasi, Universitas Stikubank. 12/TH.I, Januari, hal 7587.

Gunawan. 2016. Penggunaan QRCode Sarana Penyampaian Promosi Dan Informasi Kebun Binatang Berbasis Android, Manajemen Informatika, AMIK BSI Sukabumi. 04/TH.I, Maret, hal 16-21.

Marisa, dina. 2011. Analisis keamanan sistem login. Program Studi Ilmu Komputer, FMIPA Universitas Mulawarman. 06/TH. II, Juli, hal 64-67.

Nugraha, pasca \& Munir, rinaldi. 2011. Pengembangan aplikasi QRCode generator dan QRCode Reader dari 
data berbentuk image. Konferensi internasional informatika. Institut teknologi Bandung. Agustus, hal 18.

Pratama, adam. 2007. Pengembangan aplikasi sistem absensi karyawan dengan metode barcode pada PT. Kemenangan jaya, Fakultas sains dan teknologi, Universitas islam negeri Syarif Hidayatullah jakarta, hal 17.

Prasetyo, WE. 2012. Implementasi roaming user pada aplikasi billing berbasis client server. Universitas kristen satya wacana, hal 2-18.

Sudarno., \& Bamabang E., 2012. Analysis Tracking Online Payment System. International journal of scientific \& technology research. Hal 1

Sovia, Rini. 2010. Model alternatif pengganti teknologi smartcard untuk sistem layanan absen ujian, Teknologi informasi \& Pendidikan. 02/TH.I, September, hal 63-79.

Tominanto. 2010. Card elektrik (barcode) sebagai sistem komputerisasi rekam medis di rumah sakit medika mulya wonogiri, Apiker citra medika Nusakarta. 1/TH.1, Februari, hal 1-16.
Ulum, Bahrul. 2002. Perancangan Aplikasi Billing Warnet, Politeknik Negeri Semarang. Juli, hal 1-10. 